\title{
Environment Improvement through Community Mobilized Open Defecation Free (ODF) Movement in Nepal
}

\author{
Ram Chandra Sah
}

\begin{abstract}
Few years back, naturally a very beautiful country Nepal was facing a lot of environment related problems. One of the major reasons behind the problem was the practice of open defecation (having no toilet) by almost 98\% people of the country. This type of practice had resulted in a very worse condition because open shit or human excreta could be seen here and there. Uses of toilets indicate the status of environmental sanitation of the locality and, therefore, the worse situation was obvious.
\end{abstract}

Now, the scenario has been changed. Government of Nepal set the target of achieving the situation of basic level sanitation facilities, by $2017 \mathrm{AD}$, to the whole population of the country. It means that each and everyone will have the access of at least one toilet and Open Defecation or shit will not be found within the boundary of Nepal. For the purpose, several options were available such as: constructing toilets for each household with the full or partial investment from the government or development partners which had been practiced in the past but successful results were not found, subsidy or support to every household for constructing toilet(s), prize to the households constructing toilet(s). But all of the above options were found as failure due to the reasons such as the development of dependency syndrome, unavailability of required funds for such options, lack of ownership feeling for sustainability etc. After assessing the situation, the government of Nepal decided to formulate Sanitation and Hygiene Master Plan with the aim of solving the hindering problems and providing the way out for the success in the future. Ultimately, the Sanitation and Hygiene Master Plan (SHMP) was formulated and endorsed by the government of Nepal in 2011 AD. The Master Plan has nine principles, several strategies and some other provisions. The major beauty of the Plan is incorporated in the form of institutional set up formation, the leadership of the local formal authority at different levels, locally formulated strategic plan with the involvement of different stakeholders, partnership and harmonized as well as coordinated (among the stakeholders) approach of working. After the implementation of the SHMP, the Open Development Free (ODF) movement in the country is at a full swing which has resulted with the declaration of more than $30 \%$ districts and declaration of ODF has become a day to day business and a matter of public

Ram Chandra Sah is with Department of Water Supply and Sewerage

Ministry of Urban Development, Government of Nepal, Kathmandu, Nepal. attraction as well as a symbol of dignity or pride. The key elements of the success include: full compliance of SHMP, no subsidy or support at a blanket level but such a provision only for the marginalized groups approach, community mobilization approaches, use of different triggering tools, uses of locally planned or formulated innovative ideas and activities, getting possible helps from locally available institutions and different functional groups or organizations etc.

ODF has been accepted as the basis for achieving the state of Total Sanitation which is accepted to be achieved if all the residents (households) of the related community or the boundary level have the access and regular use of toilet(s), regular and compulsory use of soap and water at the critical moments, regular practice of use of food hygiene behavior, regular practice of use of water hygiene behavior including household level purification of locally available drinking water, maintenance of regular personal hygiene and household level waste management and the availability of the state of overall clean environment continuously at the concerned level of community or settlement. Some places of the country have been declared with the achievement of Total Sanitation.

Thus, Community Mobilized Open Defecation Free (ODF) Movement in Nepal has supported a lot for a better environmental situation of the country and it is believed that the approach can be very useful for other developing or under developed countries of the world.

Keywords - Environment, Open Defecation Free (ODF), Nepal.

\section{INTRODUCTION}

$F^{\mathrm{sw}}$ EW years back Nepal, naturally a very beautiful country, was facing a lot of environment related problems. One of the major reasons behind the problem was the practice of open defecation (having no toilet) by almost $98 \%$ people [5] of the country. This type of practice had resulted in a very worse condition because open shit or human excreta could be seen here and there. Uses of toilets indicate the status of environmental sanitation of the locality and, therefore, the worse situation was obvious. The situation has been changing in recent years. In 2011, around 62\% households were found to have access to toilets [5] which means that around $38 \%$ of the households of Nepal used to defecate at open places and, thus, were needed with the construction of toilets. Open 
defecation; through worse public health, social and economic impacts can create vicious cycle of illness; high expenditure on health care; lost work and school hours; and poverty. Due to poor hygiene and sanitary environment, the country is bearing an enormous cost, which has resulted in the loss of productivity equivalent to more than NRs.10 (about 0.10 US \$) billion, annually. Women, adolescent girls, children and infants suffer most from inadequate hygiene and lack of sanitation facilities. Acute Respiratory Infections (ARI) and diarrheal diseases are the major two causes of mortality among children under age five which are closely linked to poor water, hygiene and sanitation [3]. Human feces are the main source of diarrheal pathogens, which cause many common gastrointestinal infections. One gram of human feces can contain 10 million virus and1million bacteria [2].

The achievement of total sanitation by entire communities through the use of toilet and improved sanitation facilities and hygiene have the power to stop this cycle and help the country move towards achievement of the Millennium Development Goal as well as the National target [4]. Good sanitation practices are also related to dignity, identity and pride of people. Sanitation is important measure to prevent public health and control environment pollution. The vulnerability of people being affected by poor hygiene and sanitation in a country like Nepal has to be well addressed at all levels. Proper measure and efforts have to be made to guarantee for the people's health, growth and development.

Considering the above facts, Government of Nepal has set a target of achieving the situation of basic level sanitation facilities for the $100 \%$ household by 2017 [2]. It means that each and everyone will have the access of at least one toilet and Open Defecation or shit will not be found within the boundary of Nepal which will be resulted with a better environmental condition.

\section{MAJOR EFFORT}

For the purpose, several options were available and tried in the past. Some of them were in the form of constructing toilets for each household with the full or partial investment from the government or development partners, subsidy or support to every household for constructing toilet(s), already fixed prize to the households constructing toilet(s). But all of the above options were found as failure due to the reasons such as the development of dependency syndrome, unavailability of required funds for such options, lack of ownership feeling for sustainability etc. After assessing the situation, the government of Nepal decided to formulate Sanitation and Hygiene Master Plan with the aim of solving the hindering problems and providing the way out for the success in the future. Ultimately, the Sanitation and Hygiene Master Plan (SHMP) was formulated and endorsed by the government of Nepal in 2011 AD.

\section{A. Sanitation and Hygiene Master Plan (SHMP) and Strategies}

The Master Plan has nine guiding principles, several operational strategies and some other provisions. The principles can be summarized as follows:

\section{a. $O D F$ as the Bottom Line}

It indicates that ODF situation must be the basic criteria of the total sanitation and Post-ODF activities in the project/program are essential to gain and sustain the sanitized condition along with waste management in households as well as institutions in the community.

\section{b. Universal Access to Toilet in any Water Supply Project}

\section{c. Technology of Households Toilets}

It requires any one of the locally appropriate toilet options with permanent structures at least up to the plinth/floor level for durability and sustainability of the structure

\section{d. Mainstreaming Local Government Bodies}

Efforts of stakeholders shall be synchronized through respective DDC (District Development Committee which is a local government body at district level), VDC (Village Development Committee which is a local government body at the lowest administrative level) and Municipality level with a unified plan of action on total sanitation.

\section{e. Universe of Program Intervention}

VDC/Municipality shall be the smallest basic universe. The ODF status may however take place gradually from a settlement, ward or school catchment area to VDC/Municipality or district.

\section{f. Support Mechanism}

There is no provision for cash or hardware subsidies for the individual household. A community fund may be provided to promote hygiene and sanitation and to achieve ODF status. The size of the fund may be decided and revised from time to time by (D-WASH-CC). NSHCC (National Sanitation and Hygiene Coordination Committee) may decide financial support arrangement in order to make the sanitation program sustainable as appropriate.

\section{g. User's Friendly Facilities in Institutions}

All the institutional toilets must be users friendly. School toilets must be child, gender and disable friendly.

\section{h. Mandatory Provision of Toilets in New Built up}

Provision of toilets facilities must be made mandatory to all new households. Similarly, all new institutions also must have users friendly toilets facilities.

\section{i. Hand Washing}

Hand washing with soap must be ensured as an integral part of water supply projects and sanitation and hygiene promotion programs.

Similarly, the key operational strategies can also be summarized as follows:

- Local Bodies to be mainstreamed as a Led Agency.

- Participatory Approach Crucial for Effective, Inclusive, 
Accelerated and Sustainable Development.

- MOU-based Partnership with the DDCs, Municipalities and VDCs.

- Demand-driven Implementation of Hygiene and Sanitation Program.

- NHSCC/DWSS (Department of Water Supply and Sewerage) to Coordinate the Program at the National Level.

- Making Hygiene and Sanitation a Free-Standing Subject for Foreign Aid.

- Establishment of a District Sanitation Section in DDC.

- Reward and Recognition which includes Rastriya Sarsaphai Puraskar (National Sanitation Award), District level awards, Special award, Program level awards etc.

- Identification and Mobilization of Financial Resources which consist of National Hygiene and Sanitation Fund, Water Supply and Sanitation Budget, Institutional Water and Sanitation Budget, VDC/Municipality/DDC Fund, Resources of Local Level Organizations, Public Private Partnership, Financial Grant to Local Bodies for Accelerated Sanitation, Donor Agencies, Community Contribution etc.

- Advocacy, Education and Social Mobilization.

- Media and Communication Strategy.

- Basic Behavior Build up Mechanism.

- Research and Development.

- Knowledge Management.

- Gender Mainstreaming and Social Inclusion.

- A minimum of one third women members will be ensured committees at all levels including district level facilitators.

- The advisory team will also be composed of fair gender balance.

- All the capacity building related training, workshop will also have a fair gender balance.

- The advocacy and IEC materials will be developed by considering gender sensitivity.

- Locally appropriate support mechanisms will be introduced for landless, ultra poor, slum and people in remote areas through the decision of the district, VDC and Municipality level coordination committees.

In short, the major beauty of the Plan is incorporated in the form of institutional set up formation, the leadership of the local formal authority at different levels, locally formulated strategic plan with the involvement of different stakeholders, partnership and harmonized as well as coordinated (among the stakeholders) approach of working. After the implementation of the SHMP, the Open Development Free (ODF) movement in the country is at a full swing which has resulted with the declaration of more than $30 \%$ districts and declaration of ODF has become a day to day business and a matter of public attraction as well as a symbol of dignity or pride. The key elements of the success include: full compliance of SHMP, no subsidy or support at a blanket level but such a provision only for the marginalized groups approach, community mobilization approaches, use of different triggering tools, uses of locally planned or formulated innovative ideas and activities, getting possible helps from locally available institutions and different functional groups or organizations etc.

ODF has been accepted as the basis for achieving the state of Total Sanitation which is accepted to be achieved if all the residents (households) of the related community or the boundary level have the access and regular use of toilet(s), regular and compulsory use of soap and water at the critical moments, regular practice of use of food hygiene behavior, regular practice of use of water hygiene behavior including household level purification of locally available drinking water, maintenance of regular personal hygiene and household level waste management and the availability of the state of overall clean environment continuously at the concerned level of community or settlement. Some places of the country have been declared with the achievement of Total Sanitation.

For this change in traditional behavior and prevailing practices, the society had to be changed for better sanitary environment. The changes in the society have been brought about with the help of the approach of social movement throughout the country.

\section{B. Major Approaches of the social movement}

\section{a. Local Body Leadership :}

The whole process of the program, from planning to documentation, is accomplished under the leadership of the local body which may be in the form of district level, municipality level or Village Development Committee (VDC) level etc. There may be just one or so many organizations, GO or NGO, but always working under the local body leadership.

\section{b. Local Planning:}

The whole planning is done at the local level with the involvement and active participation of the local stakeholders. The mapping of locally available resources is done, those are planned to be utilized and locally suitable activities are planned to be run at the locally suitable period(s) of time. Obviously, the local context and potential are optimally utilized.

\section{c. Involvement of Local Institutions:}

Taking capacity and potential into consideration; local institutions such as government offices, non government offices, schools, health centers, financial institutions etc are utilized for the purpose.

\section{d. Involvement of Local Groups:}

There are so many functional groups such as different types of users' groups, mothers' groups, farmers' groups, forest groups, cultural and religious groups etc available at the local level which are identified and planned for utilization as per their capability and strength.

\section{e. Local Fund Generation:}

For the purpose, fund generation is managed with the help of different techniques such as donations from different organizations, collection against the local cultural programs, 
begging by groups of high level leaders and officers, self donation in the form of cash or kind from motivated people which is popularly known as "Daanveer Program" at the local level etc. The effective and optimum utilization procedure of such types of funds is decided at the local level.

\section{f. Involvement of Local Triggerers:}

There are many triggering tools which are used to convince people, individually or in a group. For the purpose, things are presented by trained triggerers in a touchy way so that the target group is convinced.

\section{g. Involvement of Local Religious Leaders and Celebrities:}

Local Religious Leaders have influence over the local people who follow them. Similarly, celebrities are also understood as the role model for the general people. Keeping this fact in view, they are utilized to convince people in the form of preaching or by entertaining with the intended messages.

\section{h. Involvement of Local Sanitation Commandos:}

Generally, commandos are understood as fighters for a specified purpose. In the context of sanitation, commandos are meant as a group of volunteers who are utilized to minimize the hindrance to the specified purpose of sanitation movement. They are not utilized as physical fighters but as motivators to convince an individual or a group of individuals not convinced by the local efforts.

\section{i. Intensive Residential Campaign:}

A group of trained and committed personnel is placed at the targeted locality for a specified period of time. Members of the group stay closely with the local people and behave as their neighbors or community members. They act as sanitation role model at the local level and play active role to convince people for behavior changes against sanitation problems. They also watch the open defecators at the critical times such as early in the morning and evening at the openly defecating spots and brief the open defecators about the ill effects of open defecation.

\section{j. Frequent Local Interaction:}

Frequent local interactions are made by trained personnel in the form of house to house visits or focal group discussions to convince people at the local level.

\section{k. Use of Sanitation Identity Card:}

Use of sanitation identity card plays a very crucial role to motivate people for the purpose. People with toilets are provided with such cards and they feel dignified and this approach attracts open defecators to construct and use own toilets.

\section{l. Management for Local Political Commitment:}

Political commitment plays a vital role and for the purpose, local political leaders are oriented and utilized to convince their network and followers to support the ODF campaign.

m. Awards and Recognition to the Contributors:

Awards and Recognition are provided during the ceremony in different forms to the individuals, groups, institutions or others who had contributed for the purpose.

\section{n. Development and Application of Innovative Ideas:}

Different innovative ideas are generated at the local level which becomes very useful for the local context. Such ideas may vary place to place and are applied to achieve the results effectively.

Now, the scenario has been changed and through social mobilization, some VDCs have been declared with the achievement of "Total Sanitation" based on the following indicators:

- Continuous use of toilets by all the households.

- Continuous use of soap with water by all the households at the critical moments.

- Continuous food hygiene practices by all the households.

- Continuous proper drinking water handling with domestic purification practices by all the households.

- Continuous proper personal hygiene, household sanitation practices by all the households.

- Overall clean environment of the locality 


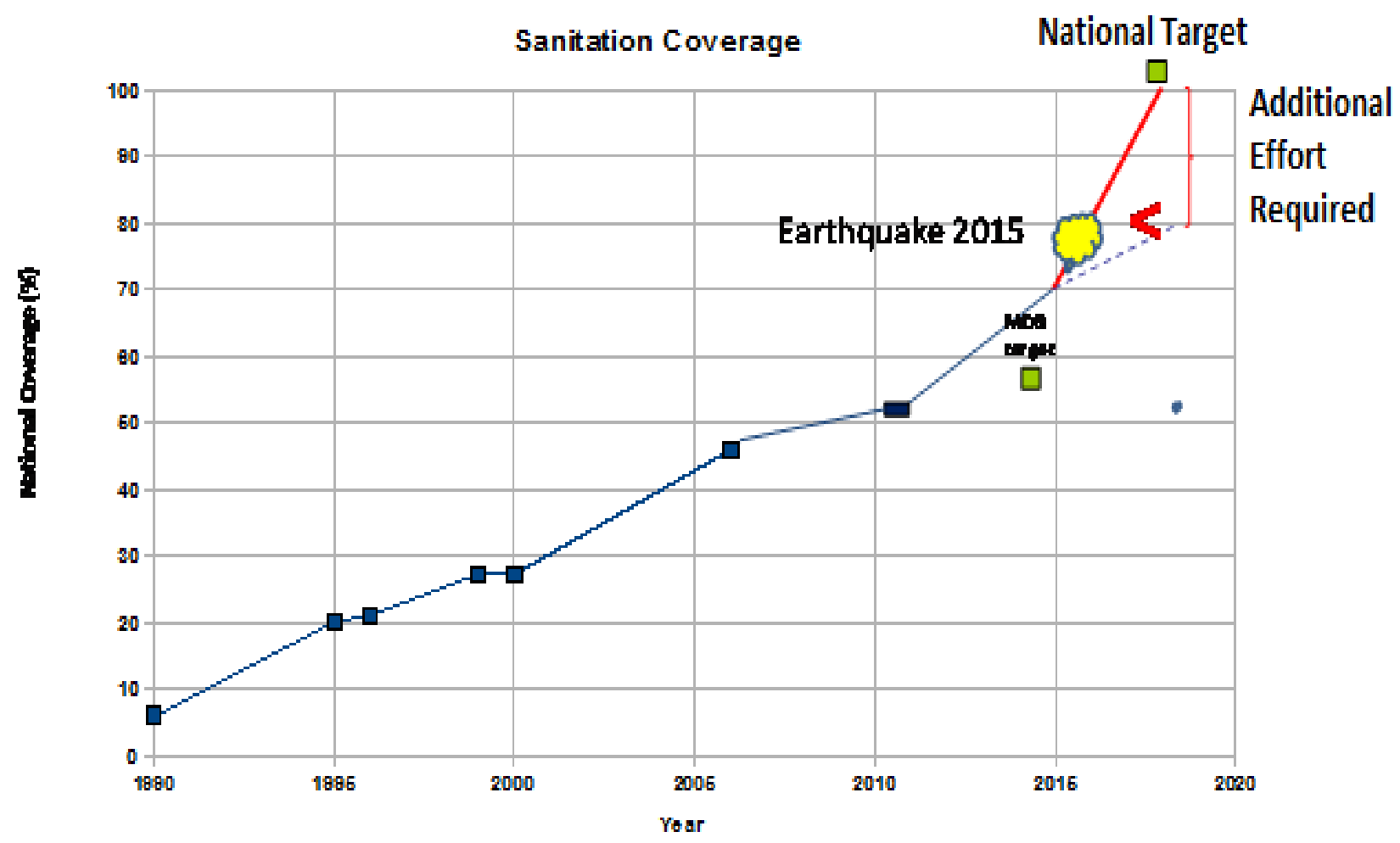

Fig. 1: Trend of growth of sanitation coverage [5]

TABLE I

Sanitation Coverage and National Targets in Percentage [2]

\begin{tabular}{|c|c|c|c|c|c|c|c|c|c|}
\hline 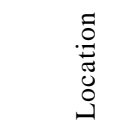 & $\begin{array}{l}\stackrel{\infty}{\infty} \\
\stackrel{2}{=}\end{array}$ & $\stackrel{2}{\circ}$ & ஓ̊ & $\stackrel{n}{8}$ & $\stackrel{0}{\stackrel{0}{0}}$ & $\bar{\Xi}$ & $\begin{array}{l}\text { ㄴ } \\
\text { ¿ }\end{array}$ & 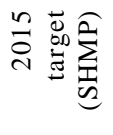 & 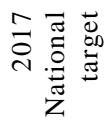 \\
\hline Urban & & $4^{3}$ & $\begin{array}{l}8 \\
0 \\
\end{array}$ & $1^{8}$ & $\begin{array}{l}7 \\
8^{7} \\
\end{array}$ & $\begin{array}{l}9 \\
1 \\
\end{array}$ & $7^{6}$ & & 100 \\
\hline Rural & & 3 & $5^{2}$ & $0^{3}$ & $7^{3}$ & $5^{5}$ & $2^{5}$ & & 100 \\
\hline National & 2 & 6 & $0^{3}$ & $9^{3}$ & $3^{4}$ & $2^{6}$ & $3^{5}$ & 80 & 100 \\
\hline
\end{tabular}

If sanitary condition of school is good, $21.7 \%$ school

A study was conducted by me in 2013 to assess some facts regarding the sanitation movement in the country. The study area comprised of one municipality, one semi urban VDC and one remote hilly VDC. Based on a total sample size of 352 households with $65 \%$ male and $35 \%$ female respondents and all the government schools of the localities, some interesting results were found as follows:

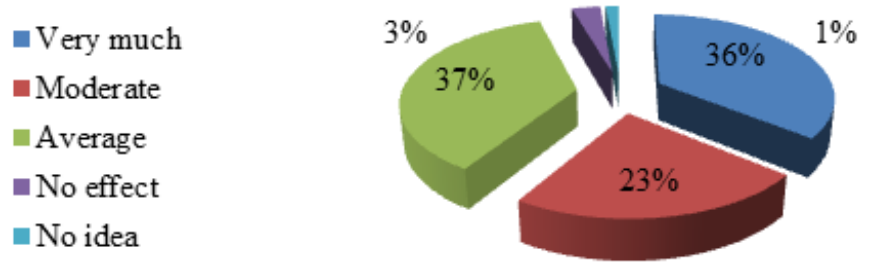

Fig. 2: Perceptions of Local People on Health Improvement by ODF catchments have complete ODF whereas with average sanitary condition, only $9.9 \%$ catchments enjoy complete ODF as shown in Figure 4.40. ODF is directly related to environment and so, the impact of ODF is the impact on environment.

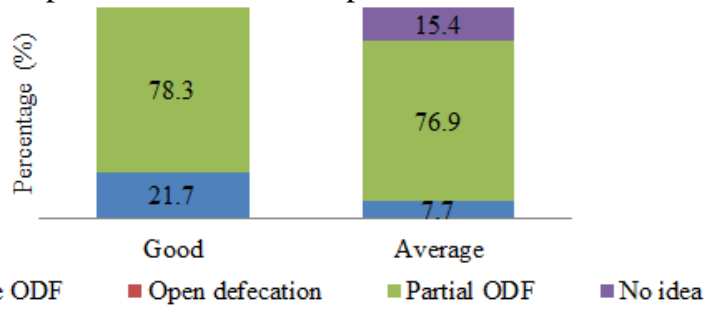

$\because$ Complete ODF $\quad$ Open defecation $\quad$ Partial ODF No idea

Fig. 3: Sanitary Condition of School vs. ODF of Catchment Area

Indication is that if the schools have a better sanitary condition, there are more chances of sustaining the ODF of the 
school catchment. The reason is that the school is the real learning and behavior changing place which results in the positive effects in the catchment of the school area.

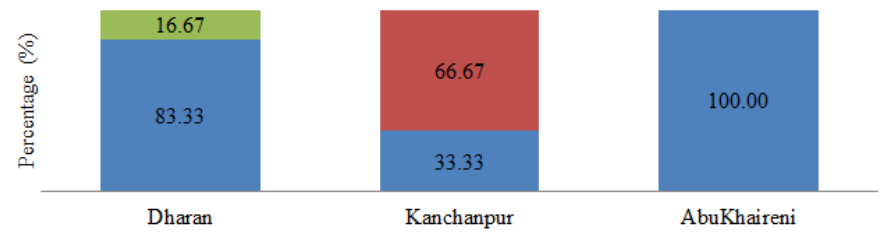

Fig. 4: Reasons of Violating ODF

Major causes of violation of ODF are lack of awareness creation or less focus on awareness activities, lack of behavior changes, lack or inadequate availability of public toilets, existing toilets are not upto the standard of using or technically problematic or lacking maintenance or lacking proper cleaning, lack of post ODF efforts, passiveness of the local working or management committee.

It indicates that hardware facilities or supports can not merely stop the violation of ODF but software activities to change mindset and proper management may be favorable to stop the violation of the ODF status.

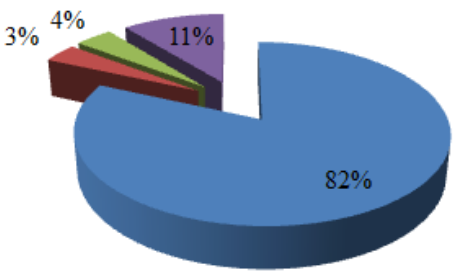

$$
\begin{aligned}
& \text { - VDC/Muncipality } \\
& \text { - NGO/INGO/Donars, etc } \\
& \text { — Government office } \\
& \text { - Participatory management }
\end{aligned}
$$

Fig. 6: Overall Responsibility of Management for ODF

The study reveals that local governments like VDC or Municipality have the major responsibility and participatory approach also plays very important role for ODF sustainability which is in line with the principle of the Sanitation and Hygiene Master Plan 2011.

Thus, Community Mobilized ODF Movement in Nepal has supported a lot for a better environmental situation of the country and it is believed that the social mobilization approach can be very useful for other developing or under developed countries of the world.

\section{ACKNOWLEDGMENT}

I am thankful to Emirates Association of Chemical, Biological and Environment Engineers for providing me an opportunity for publishing this paper. I would like to extend my sincere thanks to Department of Water Supply and Sewerage of Nepal and UNICEF Nepal to support me throughout the study which enabled me for preparing this paper. My sincere thanks go to all the respondents; Water Supply and Sanitation Division offices of Itahari (Sunsari), Rajbiraj (Saptari) and Damauli (Tanahun); Dharan Municipality Office, Sunsari; Kanchanpur VDC Office of Saptari; Aanbukhaireni VDC Office of Tanahun. I would like to express my honest thanks to all the stakeholders and personnel devoted to the upliftment of and movement for the sanitation situation of the nooks and corners of Nepal.

\section{REFERENCES}

[1] CBS, 2011. Report on National Population Census. Kathmandu: Central Bureau of Statistics, Government of Nepal (GoN).

[2] GoN, 2011. Sanitation and Hygiene Master Plan. Kathmandu: National Sanitation and Hygiene Coordination Committee, Government of Nepal $(\mathrm{GoN})$.

[3] MoHP, 2011. Nepal Demographic and Health Survey. Kathmandu: Ministry of Health and Population (MoHP), Government of Nepal $(\mathrm{GoN})$.

[4] WHO and UNICEF, 2004. Joint Monitoring Program for Water Supply and Sanitation. Kathmandu: Government of Nepal.

[5] NMIP Report, 2015. Department of Water Supply and Sewerage, Kathmandu: Government of Nepal. 